\title{
Low concentrations of methamphetamine can suppress inflammation in trophoblast JEG-3 cell line induced by nicotine
}

\author{
Zhaleh $\mathrm{H}^{1}$, Amer Ridha $\mathrm{A}^{2}$, Amini $\mathrm{K}^{3}$ \\ Substance Abuse Prevention Research Center, Institute of Health, Kermanshah University of Medical Sciences, \\ Kermanshah, Iran. hossain_jale@yahoo.com
}

\begin{abstract}
AIM: Nicotine at high concentrations induces apoptosis in trophoblastic cells through induction of cell cytotoxicity and Reactive Oxygen Species (ROS). Methamphetamine in low dose has pharmaceutical properties. It seems that this components in low dose can protect the trophoblastic cells from nicotineinduced cell death.

METHOD: Trophoblastic (JEG-3) cells grown in DMEM culture medium. MTT assay test detected the cell viability and Lactate Dehydrogenase test measured the cells cytotoxicity. Griess reaction was used for NO production analysis. Cell migration traced by wounding technique. Human Cytokine Array Focused 13-plex was also used for analysis of IL-1 $\alpha$, IL-1 $1 \beta$, IL-6, INFy, and TNF $\alpha$ pre-inflammatory cytokines.

RESULTS: Methamphetamine, in very low dose (pM), increased the cell viability and NO production, and decreased cell cytotoxicity, IL-1 $\alpha$, IL-1 $\beta$, IL-6, INFY, and TNF $\alpha$ pre-inflammatory cytokines of JEG-3 cell which were exposed to high dose of nicotine, respectively. Cell migration was enhanced by low dose of methamphetamine in JEG-3 cells.

CONCLUSION: Methamphetamine in very low dose suppressed the JEG-3 cell death induced by high dose of nicotine (Fig. 5, Ref. 48). Text in PDF www.elis.sk.

KEY WORDS: methamphetamine, nicotine, cell death, NO.
\end{abstract}

\section{Introduction}

Nicotine is an alkaloid found in the tobacco plant as a most important addictive compound and it has devastating effects on global health because of rising smoking rates $(1,2)$. Nicotine concentration in the blood increases in people who have long-term smoked, and often acts as an agonist for nicotinic acetylcholine receptors (3-5). Although in various organs, such as heart, kidneys, intestines and lungs it has adverse effects and causes diseases, it's most important effects are in the central nervous system, causing various disorders and anomalies (6-8). On the other hand, nicotine has the potential to induce mutations in the genetic material of the cells, in particular the epithelial cells of the intestine, cervix, urinary bladder, stomach, lungs, colon, breast, and mouth and can trigger the first step in cancer development by stimulating cellular

${ }^{1}$ Substance Abuse Prevention Research Center, Institute of Health, Kermanshah University of Medical Sciences, Kermanshah, Iran, ${ }^{2}$ Department of Dentistry, AL-Zahrawi University College, Holy Karbala, Iraq, and ${ }^{3}$ Department of Biotechnology, Faculty of Advanced Science and Technology, University of Isfahan, Isfahan, Iran

Address for correspondence: $\mathrm{H}$. Zhaleh, Dr, PhD, Substance Abuse Prevention Research Center, Institute of Health, Kermanshah University of Medical Sciences, Kermanshah, Iran. transfusion (9-13). High dose nicotine can cause ROS production and has an apoptotic effect on cell cultures, but low dose has protective effect on neuronal cells. Gao, T et, al in a study, stated that nicotine has no effect on cell growth in low concentrations $(0.01 \mu \mathrm{M})$, but at high concentrations $(0.1 \mu \mathrm{M}, 1 \mu \mathrm{M}$ and $10 \mu \mathrm{M})$ significantly inhibits cell growth of A549 cells (14). Nicotine activates the AChRs receptor as a neuronal nicotinic acetylcholine receptor, which induces p53 protein as a tumor suppressor and proteins p21 as a cell cycle inhibitor (15). Nicotinic acetylcholine receptors of Purkinje cell's which are activated by nicotine can trigger apoptotic process that ultimately reduces the Purkinje cell population (16).

Methamphetamine is a stimulant used in the several past decades as a drug for treating attention-deficit hyperactivity, narcolepsy and obesity, and increased consciousness (17-19). Methamphetamine leads to dopamine, norepinephrine, and serotonin release $(20,21)$, also it cause an increase in satisfaction, attention and strength. Myocardial infarction, concussion, annexation, rhabdomyolysis and psychosis are the most important methamphetamine side effects which may eventually cause death (22-24).

JEG-3 choriocarcinoma cell line as a monoclonal and highly proliferative trophoblastic model was selected, which is derived from a human choriocarcinoma and shows the biological and biochemical properties of syncytiotrophoblasts $(25,26)$. Although 
morphine and methamphetamine in high concentrations can cause cell death due to cell cytotoxicity and apoptotic events, in very low concentration both of them seem to protect cultured cells from induced death. Therefore, we tried to study the possible protective effects of morphine and methamphetamine in different concentrations on nicotine-induced cell death of JEG-3 cell line. In this study cell viability, cytotoxicity, NO production, cell migration and neurotic factors such as IL1 $\alpha$, IL1 $\beta$, IL6, INF $\gamma$ and TNF $\alpha$, in different concentrations of methamphetamine and constant concentration of nicotine, which leads to cell death, were obtained and protective potency of both drugs was analyzed.

\section{Materials and methods}

\section{Cell culture}

In this study, DMEM culture medium (Gibco) was used in T-25 $\mathrm{cm}^{2}$ tissue culture flasks and JEG-3 cell were cultured in this media which contained supplementary compounds as listed below: $10 \%$ fetal bovine serum (FBS, Gibco), $1 \%$ non-essential amino acid (NEAA, Sigma), 2 mM L-glutamine (Sigma), 100 IU/ml penicillin (Sigma), and $100 \mu \mathrm{g} / \mathrm{ml}$ streptomycin (Sigma). Incubation of the cell culture was performed at $37^{\circ} \mathrm{C}$ in $5 \% \mathrm{CO}_{2}$ medium, once in every two days. Trypsin-EDTA $0.25 \%$ (Sigma) was used for trypsination of cell cultures. $1 \times 10^{4}$ cells/well was final density of the cells in 24-well culture plates.

\section{Treatment}

The cells were washed by PBS, pH 7.4 after a day of cell plating. Two groups of treatments were performed: Control: culture medium, Treatment 1: $1 \mathrm{mM}$ nicotine, Treatment 2: $1 \mathrm{mM}$ nicotine and $1 \mathrm{pM}$ Methamphetamine, Treatment 3:1 mM nicotine and $10 \mathrm{pM}$ Methamphetamine, Treatment 4: $1 \mathrm{mM}$ nicotine and $100 \mathrm{pM}$ Methamphetamine, Treatment 5: $1 \mathrm{mM}$ nicotine and $1 \mathrm{nM}$ Methamphetamine, Treatment 6: $1 \mathrm{mM}$ nicotine and $10 \mathrm{nM}$ Methamphetamine, and Treatment 7: $1 \mathrm{mM}$ nicotine and $100 \mathrm{nM}$ Methamphetamine.

\section{Cell viability (\%) (MTT assay)}

$15 \times 10^{3}$ cells were loaded into $96-w e l l$ plates. $200 \mu \mathrm{L}$ of DMEM media containing $0.2 \%$ BSA was added to each plate. An enzymelinked immunosorbent assay (ELISA) reader measured the optical density of the wells at 570 and $630 \mathrm{~nm}$.

\section{Cytotoxicity}

The cells were plated in 24 well culture plates with density of $10^{4}$ cells $/ \mathrm{mL}$. Damaged cells release Lactate dehydrogenase (LDH) into the environment, so concentration of LDH indicates the cell cytotoxicity. An ELISA Reader (EL800; USA) measured the activity of LDH at 490 or $492 \mathrm{~nm}$ and reference wavelength of more than $600 \mathrm{~nm}$. All experiments were replicated at least three times.

\section{Nitric oxide test}

An ELISA Reader measured the level of nitric oxide in different treatments after incubation of the cells in $37^{\circ} \mathrm{C}$ for $30 \mathrm{~min}$. In this study, Griess reaction was performed for measurement of the amount of NO production in different treatments (27).

\section{Migration assay}

In this study, for assessment of cell migration, cells were plated in 6 well culture plates at confluent density. A sterile razor blade was used to perform the wounding in different treatments, after pressure induction. After washing the monolayer of wounded cells, the regions for more analyzing were selected based on the previous study (28). The cells were then incubated for $24 \mathrm{~h}$ with culture medium, fixed and cells that had migrated from demarcation line were counted in random six fields under phase contrast microscopy.

\section{Cytokines}

In this study, Human Cytokine Array Focused 13-plex was used for measurement of IL- $1 \alpha$, IL-1 $\beta$, IL- 6 , INF $\gamma$, and TNF $\alpha$ pre-inflammatory cytokines in different treatments. The cells were exposed to different treatments for $48 \mathrm{~h}$ and activity of these cytokines were measured based on the company's protocol.

\section{Results}

\section{Cell viability}

MTT results showed that viability of treatment1 reached zero percent. It means that nicotine disrupted the neurotic cells at a high dose. Results of treatments 2-7 revealed that methamphetamine has improved the viability of the cells in very low concentration. An Intragroup significant difference was observed in cell viability of treatments 2-7 (p<0.05) (Fig. 1).

\section{Cell cytotoxicity}

LDH test revealed that nicotine increased the cell cytotoxicity of JEG-3 cells in high dose. The cell cytotoxicity of treatment 1 (nicotine) was near to $100 \%$. Methamphetamine in low concentration decreased cell cytotoxicity of the cells which were exposed to cytotoxic concentration of nicotine. The cell cytotoxicity of treatments 2-5 was significantly different with treatment 1 (nicotine group). A significant intragroup difference was observed between treatments $2-7$ ( $p<0.05)$ (Fig. 2).

Nitric oxide

Production of NO in treatment1 (nicotine group) was so high. High concentration of NO leads to cell death. Methamphetamine

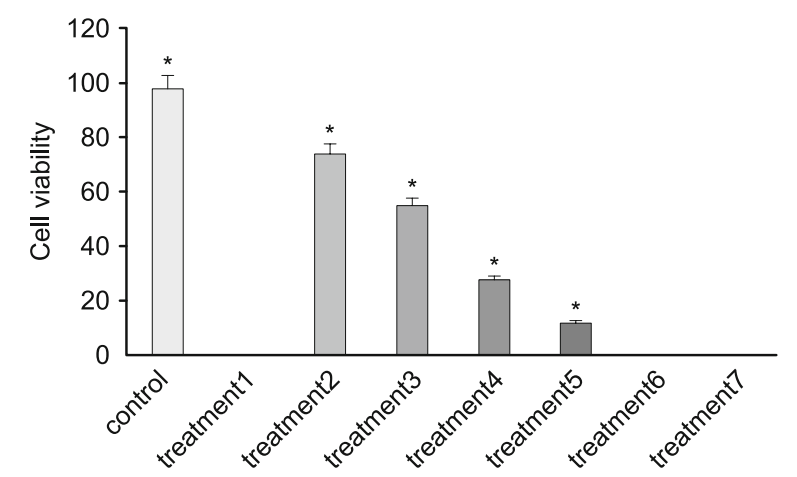

Fig. 1. The cell viability of different treatment media on JEG-3 cells after $48 \mathrm{~h}$. 


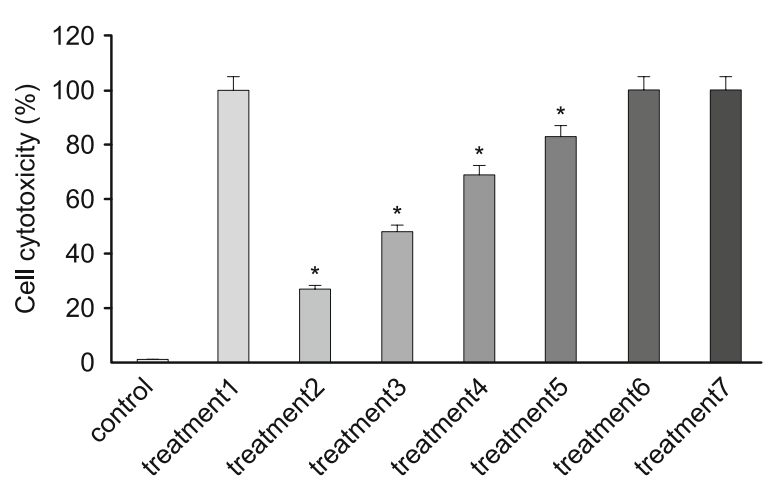

Fig. 2. The cell cytotoxicity of different treatment media on JEG-3 cells after $48 \mathrm{~h}$.

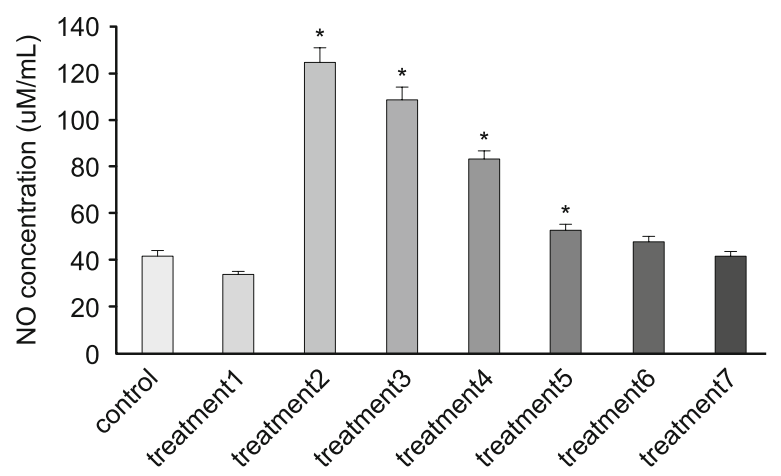

Fig. 3. The amount of nitric oxide production of different treatment media on JEG-3 cells after $48 \mathrm{~h}$.

in very low concentration suppressed the production of NO. Treatment 2 suppressed NO production most effectively. NO production in treatments $2-5$ were lower than treatment1 (nicotine group) significantly. A significant intragroup difference was observed between treatments $2-7(\mathrm{p}<0.05)$ (Fig. 3).

\section{Migration assay}

High dose of nicotine in treatment 1 suppressed cell migration significantly. Treatments $2-7$ effectively suppressed the antimigration efforts of high dose nicotine. The results of treatment 2 cell migration showed the most effective enhancement in cell migration in methamphetamine treatments. A significant intragroup difference was observed between treatments $2-7$ ( $p<0.05)$ (Fig. 4).

\section{Cytokines}

The concentration of IL- $1 \alpha$, IL-1 $\beta$, IL- 6, INF $\gamma$, and TNF $\alpha$ pre-inflammatory cytokines in treatment 1 (nicotine group) increased significantly. High doses of pre-inflammatory cytokines lead to inflammation and disruption of neurotic cells. Treatments $2-5$ decreased the production of these pre-inflammatory cytokines significantly. Treatment 2 decreased the production of these cytokines more effectively than other treatments. A significant intragroup difference was observed between treatments $2-7$ $(\mathrm{p}<0.05)$ (Fig. 5).

\section{Discussion}

During pregnancy, smoking has devastating effects on the fetus. Nicotine deregulates the neurodevelopment when fetus is exposed to it. It may lead to psychiatric problems, such as substance abuse (29). Nicotine disrupts the trophoblastic cells and induces apoptosis in these cells. There is a hypothesis that explains nicotine initiates the production of free radicals. Free radicals result in reactive oxygen species which promote the inflammation through the increase of inflammatory cytokines production (30-32). Increase of knowledge about that can help us to control neurotic diseases induced by nicotine. A study revealed that nicotine promotes free radicals in JEG-3 cells, a transformed cell line of trophoblastic origin, and vitamin $\mathrm{C}$ and $\mathrm{E}$ can scavenge these radicals and protect the placental cells from nicotine induced cell death (33). Methamphetamine was initially used at very low-dose as a drug for sleep deprivation (34). It also increases awareness, weight and self-confidence (35-37). High concentrations of methamphetamine can induce cell death in neuronal cell lines, but in low concentrations, it may exhibit different behavioral patterns and protect

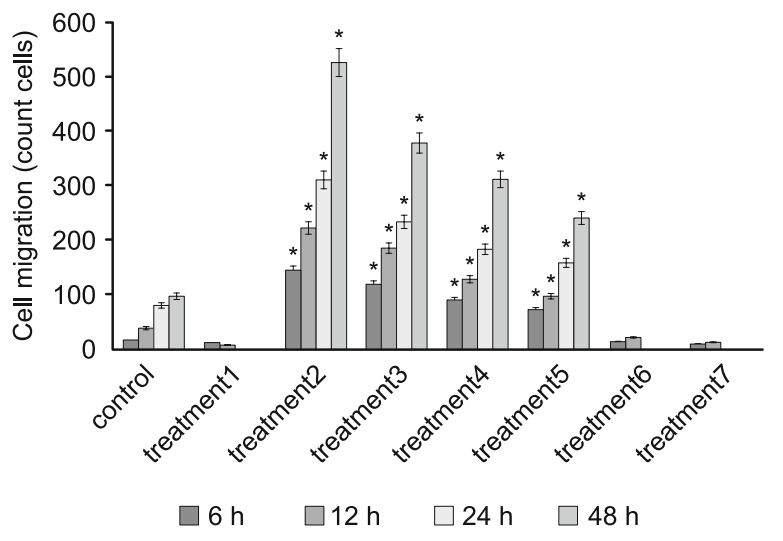

Fig. 4. Results of migration assay of different treatment media on JEG-3 cells after 6 h, 12 h, 24 h, and 48 h.

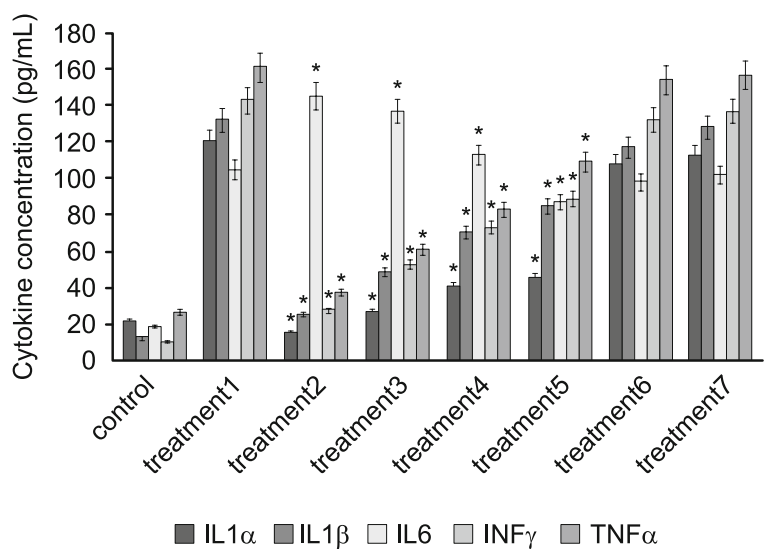

Fig. 5. Results of pre-inflammatory cytokines assay of different treatment media on JEG-3 cells after 6 h, 12 h, 24 h, and 48 h. 
nerve cells from cell death (38). Dopamine and norepinephrine are involved in low-dose methamphetamine neuroprotective effects $(39,40)$. Nitric oxide signaling is suggested as main pathway which enhances the phosphorylation of PI3K. Also, it can increase the expression of pAKT (41). Our experiments showed that low dose methamphetamine increases the production of NO in a dose-dependent manner. Impact of NO observed in increase of reactive oxygen species and free radicals which start the inflammation process that leads to apoptosis of placenta and neuronal cells $(42,43)$. In this study, we reported that methamphetamine, in dose-dependent manner, induced the production of NO in JEG-3, whereas high concentration nicotine suppressed its production. NO affects the production of pre-inflammatory cytokines which lead to neuroinflammation as a most important cause of cell death in nerve system (44-46). NO, and ROS are involved in immune system regulation and they present complex modulating effects on the inflammatory process in the brain (47). A previous study indicated that infiltration of neutrophils and activation of microglia reduces when reuptake of serotonin is blocked. Furthermore, this blocking reduces the activity of NF-kappaB pro-inflammatory factor (48). In this study, we demonstrated that inflammation was suppressed by NO production induced by methamphetamine. Methamphetamine reduced the concentration of the IL $1 \alpha$, IL $1 \beta$, IL6, INF $\gamma$, and TNF $\alpha$ proinflammatory cytokines in high-dose nicotine treated JEG-3 cells. Reduction of these cytokines by methamphetamine leads to suppression of inflammation and protection of nerve cells from nicotine induced cell death in a dose-dependent manner. A previous study showed that opioids decreased expression of X subunit, the immunoproteasome catalytic subunit LMP7, and activity of 20S proteasome which were increased by rotenone. These events lead to suppression of inflammation via NO. Increase of free ubiquitin by opioids indicates that it reduces the oxidized proteins through degradation and protects the neuronal cells from inflammation and death (45). Finally, the results of cell migration revealed that methamphetamine protects JEG-3 cells from nicotine-induced cell death in a dose-dependent manner.

\section{Conclusion}

In this study, we concluded that methamphetamine, in a dosedependent manner, can protect JEG-3 cells from effects of high dose nicotine. Very low dose methamphetamine suppressed the JEG-3 cell death which was caused by high dose of nicotine through the production of $\mathrm{NO}$ and inhibition of pro-inflammatory cytokines.

\section{References}

1. Benowitz NL. Neurobiology of nicotine addiction: implications for smoking cessation treatment. Amer J Med 2008; 121 (4): S3-S10.

2. Tuchila C, Baconi DL, Dinu Pirvu C, Balalau DO, Vlasceanu AM, Stan $\mathbf{M}$ et al. Therapeutic drug monitoring and methods of quantitation for carbamazepine. J Mind Med Sci 2017; 4 (2): 100-114.

3. Hukkanen J, Jacob P, Benowitz NL. Metabolism and disposition kinetics of nicotine. Pharmacol Rev 2005; 57 (1): 79-115.
4. Dennis PA, Van Waes C, Gutkind JS, Kellar KJ, Vinson C, Mukhin AG et al. The biology of tobacco and nicotine: bench to bedside. AACR; 2005.

5. Dasgupta P, Rastogi S, Pillai S, Ordonez-Ercan D, Morris M, Haura E et al. Nicotine induces cell proliferation by $\beta$-arrestin-mediated activation of Src and Rb-Raf-1 pathways. J Clin Invest 2006; 116 (8): 2208-2217.

6. Kim CS, Choi JS, Joo SY, Bae EH, Ma SK, Lee J et al. Nicotineinduced apoptosis in human renal proximal tubular epithelial cells. PLoS One 2016; 11 (3): e0152591.

7. Rossing P, Hougaard P, Parving H-H. Risk factors for development of incipient and overt diabetic nephropathy in type 1 diabetic patients: a 10-year prospective observational study. Diabet Care 2002; 25 (5): 859-864.

8. Urakawa N, Nagata T, Kudo K, Kimura K, Imamura T. Simultaneous determination of nicotine and cotinine in various human tissues using capillary gas chromatography/mass spectrometry. Internat J Legal Med 1994; 106 (5): 232-236.

9. Macklin KD, Maus AD, Pereira EF, Albuquerque EX, Conti-Fine BM. Human vascular endothelial cells express functional nicotinic acetylcholine receptors. J Pharmacol Exp Ther 1998; 287 (1): 435-439.

10. Mishra A, Chaturvedi P, Datta S, Sinukumar S, Joshi P, Garg A. Harmful effects of nicotine. Indian J Med Paediatr Oncol 2015; 36 (1): 24.

11. Schaal C, Chellappan SP. Nicotine-mediated cell proliferation and tumor progression in smoking-related cancers. Mol Cancer Res 2014; 12 (1): 14-23.

12. Ginzkey C, Stueber T, Friehs G, Koehler C, Hackenberg S, Richter E et al. Analysis of nicotine-induced DNA damage in cells of the human respiratory tract. Toxicol Lett 2012; 208 (1): 23-29.

13. Grando SA. Connections of nicotine to cancer. Nature Rev Cancer 2014; 14 (6): 419.

14. Gao T, Zhou X-L, Liu S, Rao C-X, Shi W, Liu J-C. In vitro effects of nicotine on the non-small-cell lung cancer line A549. J Pak Med Assoc 2016; 66 (4): 368-372.

15. Berger F, Gage FH, Vijayaraghavan S. Nicotinic receptor-induced apoptotic cell death of hippocampal progenitor cells. J Neurosci 1998; 18 (17): 6871-6881.

16. Strahlendorf JC, Acosta S, Miles R, Strahlendorf HK. Choline blocks AMPA-induced dark cell degeneration of Purkinje neurons: potential role of the $\alpha 7$ nicotinic receptor. Brain Res 2001; 901 (1-2): 71-78.

17. Skrabalova J, Karlovska I, Hejnova L, Novotny J. Protective effect of morphine against the oxidant-induced injury in $\mathrm{H} 9 \mathrm{c} 2$ cells. Cardiovasc Toxicol 2018; 18 (4): 374-385.

18. Matsumoto T, Kamijo A, Yamaguchi A, Iseki E, Hirayasu Y. Childhood histories of attention-deficit hyperactivity disorders in Japanese methamphetamine and inhalant abusers: Preliminary report. Psychiatr Clin Neurosci 2005; 59 (1): 102-105.

19. Kanbayashi T, Honda K, Kodama T, Mignot E, Nishino S. Implication of dopaminergic mechanisms in the wake-promoting effects of amphetamine: a study of D-and L-derivatives in canine narcolepsy. Neuroscience 2000; 99 (4): 651-659.

20. Rothman RB, Baumann MH, Dersch CM, Romero DV, Rice KC, Carroll FI et al. Amphetamine-type central nervous system stimulants release norepinephrine more potently than they release dopamine and serotonin. Synapse 2001; 39 (1): 32-41. 
21. Negus S, Mello N, Blough B, Baumann M, Rothman R. Monoamine releasers with varying selectivity for dopamine/norepinephrine versus serotonin release as candidate "agonist" medications for cocaine dependence: studies in assays of cocaine discrimination and cocaine self-administration in rhesus monkeys. J Pharmacol Exp Ther 2007; 320 (2): 627-636.

22. Silber BY, Croft RJ, Papafotiou K, Stough C. The acute effects of d-amphetamine and methamphetamine on attention and psychomotor performance. Psychopharmacology 2006; 187 (2): 154-169.

23. Mooney ME, Herin DV, Schmitz JM, Moukaddam N, Green CE, Grabowski J. Effects of oral methamphetamine on cocaine use: a randomized, double-blind, placebo-controlled trial. Drug Alcohol Dependence 2009; 101 (1-2): 34-41.

24. Shariatirad S, Maarefvand M, Ekhtiari H. Methamphetamine use and methadone maintenance treatment: an emerging problem in the drug addiction treatment network in Iran. Internat J Drug Policy 2013; 24 (6): e115-e116.

25. Matsuo H, Strauss 3rd J. Peroxisome proliferators and retinoids affect JEG-3 choriocarcinoma cell function. Endocrinology 1994; 135 (3): $1135-1145$.

26. Blanchon L, Sauvant P, Bavik C, Gallot D, Charbonne F, Alexandre-Gouabau M-C et al. Human choriocarcinoma cell line JEG-3 produces and secretes active retinoids from retinol. Mol Human Reprod 2002; 8 (5): 485-493.

27. Sun J, Zhang X, Broderick M, Fein H. Measurement of nitric oxide production in biological systems by using Griess reaction assay. Sensors 2003; 3 (8): 276-284.

28. Irving J, Lala P. Functional role of cell surface integrins on human trophoblast cell migration: regulation by TGF- $\beta$, IGF-II, and IGFBP-1. Exp Cell Res 1995; 217 (2): 419-427.

29. Ernst M, Moolchan ET, Robinson ML. Behavioral and neural consequences of prenatal exposure to nicotine. J Amer Acad Child Adolescent Psychiatr 2001; 40 (6): 630-641.

30. Coleman T, Antoniak M, Britton J, Thornton J, Lewis S, Watts K. Recruiting pregnant smokers for a placebo-randomised controlled trial of nicotine replacement therapy. BMC Health Services Res 2004; 4 (1): 29.

31. Dempsey DA, Benowitz NL. Risks and benefits of nicotine to aid smoking cessation in pregnancy. Drug Safety 2001; 24 (4): 277-322.

32. Vaglenova J, Birru S, Pandiella NM, Breese CR. An assessment of the long-term developmental and behavioral teratogenicity of prenatal nicotine exposure. Behav Brain Res 2004; 150 (1-2): 159-170.

33. Gallo C, Renzi P, Loizzo S, Loizzo A, Piacente S, Festa M et al. Potential therapeutic effects of vitamin $\mathrm{E}$ and $\mathrm{C}$ on placental oxidative stress induced by nicotine: an in vitro evidence. Open Biochem J 2010; 4: 77.
34. Mahoney III JJ, De La Garza II R, Jackson BJ, Verrico CD, Ho A, Iqbal $\mathbf{T}$ et al. The relationship between sleep and drug use characteristics in participants with cocaine or methamphetamine use disorders. Psychiatr Res 2014; 219 (2): 367-371.

35. Cadet JL, Bisagno V. Neuropsychological consequences of chronic drug use: relevance to treatment approaches. Front Psychiatry 2016; 6: 189.

36. Mitler MM, Hajdukovic R, Erman MK. Treatment of narcolepsy with methamphetamine. Sleep 1993; 16 (4): 306-317.

37. Morgenthaler TI, Kapur VK, Brown TM, Swick TJ, Alessi C, Aurora $\mathrm{RN}$ et al. Practice parameters for the treatment of narcolepsy and other hypersomnias of central origin. Sleep 2007; 30 (12): 1705-1711.

38. Rau TF, Kothiwal A, Zhang L, Ulatowski S, Jacobson S, Brooks DM et al. Low dose methamphetamine mediates neuroprotection through a PI3K-AKT pathway. Neuropharmacology 2011; 61 (4): 677-686.

39. Thrash B, Thiruchelvan K, Ahuja M, Suppiramaniam V, Dhanasekaran M. Methamphetamine-induced neurotoxicity: the road to Parkinson's disease. Pharmacol Report 2009; 61 (6): 966-977.

40. Junker V, Becker A, Hühne R, Zembatov M, Ravati A, Culmsee $\mathbf{C}$ et al. Stimulation of $\beta$-adrenoceptors activates astrocytes and provides neuroprotection. Eur J Pharmacol 2002; 446 (1-3): 25-36.

41. Patel NJ, Chen MJ, Russo-Neustadt AA. Norepinephrine and nitric oxide promote cell survival signaling in hippocampal neurons. Eur J Pharmacol 2010; 633 (1-3): 1-9.

42. Coleman JW. Nitric oxide in immunity and inflammation. Internat Immunopharmacol 2001; 1 (8): 1397-1406.

43. Sarih Mh, Souvannavong V, Adam A. Nitric oxide synthase induces macrophage death by apoptosis. Biochem Biophys Res Commun 1993; 191 (2): 503-508.

44. Saijo K, Winner B, Carson CT, Collier JG, Boyer L, Rosenfeld MG et al. A Nurr1/CoREST pathway in microglia and astrocytes protects dopaminergic neurons from inflammation-induced death. Cell 2009; 137 (1): 47-59.

45. Cookson BT, Brennan MA. Pro-inflammatory programmed cell death. Trends Microbiol 2001; 9 (3): 113-114.

46. Brown GC, Bal-Price A. Inflammatory neurodegeneration mediated by nitric oxide, glutamate, and mitochondria. Mol Neurobiol 2003; 27 (3): $325-355$.

47. Guzik T, Korbut R, Adamek-Guzik T. Nitric oxide and superoxide in inflammation. J Physiol Pharmacol 2003; 54: 469-487.

48. Lim CM, Kim SW, Park JY, Kim C, Yoon SH, Lee JK. Fluoxetine affords robust neuroprotection in the postischemic brain via its anti-inflammatory effect. J Neurosci Res 2009; 87 (4): 1037-1045. 